\title{
The effect of room temperature control by air- or operative temperature on thermal comfort
} and energy use

\author{
Bjarne W. Olesen ${ }^{1}$, Haiying Wang ${ }^{1,2}$, Ongun B. Kazanci ${ }^{1}$, Daniel Coakley ${ }^{3}$ \\ ${ }^{1}$ International Centre for Indoor Environment and Energy, Department of Civil Engineering, \\ Technical University of Denmark, Nils Koppels Alle 402, 2800 Kgs. Lyngby, Denmark \\ ${ }^{2}$ Department of Environment and Municipal Engineering, Qingdao University of Technology, No. \\ 11 Fushun Road, Qingdao, China \\ ${ }^{3}$ Mitsubishi Electric R\&D Centre Europe BV, 17 Firth Road (AC3), Houston Industrial Estate, \\ Livingston, West Lothian EH54 5DJ
}

\begin{abstract}
The most commonly used thermostat control variable in heating, ventilating and air-conditioning systems is air temperature. The requirement for thermal comfort in international standards are however based on operative temperature. Will the adoption of operative temperature based control lead to better thermal comfort and how will this affect the energy use? The position and type of thermostat may also influence the comfort in the occupied zone. These questions were studied by simulations of three heating and cooling systems, fan-coil system (convective system) and two radiant systems: floor heating/cooling system and radiant ceiling heating/cooling panel system in three different geographical locations (Copenhagen, Paris and Rome). Besides the simulations, the influence of the position was tested in an experimental room with a convective and a radiant heating/cooling system.
\end{abstract}

\section{Introduction}

Several indoor environmental parameters influence thermal comfort of the occupants. In all existing international standards for the indoor environment, the requirements for the thermal environment and the room temperature are given by using the operative temperature as reference (ISO EN 7730, EN 16798-1, ISO 17772-1, ASHRAE 55). The operative temperature is defined as the uniform temperature of an enclosure where a person would exchange the same amount of heat by radiation plus convection as in the actual non-uniform environment (ISO EN 7730). Thus the sensor should represent the same ratio of heat exchange as the person.

The operative temperature can be expressed as:

$$
t_{o}=\frac{\left(h_{c} \cdot t_{a}+h_{r} \cdot t_{r}\right)}{\left(h_{c}+h_{r}\right)},
$$

Where, $t_{o}$ is the operative temperature, $t_{a}$ is the air temperature, $\mathrm{t}_{r}$ is the mean radiant temperature $\left({ }^{\circ} \mathrm{C}\right), h_{c}$ is the convective heat exchange coefficient, and $h_{r}$ is the radiant heat exchange coefficient for a person $\left(\mathrm{W} / \mathrm{m}^{2} \mathrm{~K}\right)$.

In practice, in most cases where air velocity is small $(<0.2$ $\mathrm{m} / \mathrm{s}$ ) or where the difference between mean radiant temperature and air temperature is small $\left(<4{ }^{\circ} \mathrm{C}\right)$, the operative temperature can calculated with sufficient approximation as the mean value of air and mean radiant temperature:

$$
t_{o}=\frac{\left(t_{a}+t_{r}\right)}{2},
$$

This means that air temperature and mean radiant temperature are equally important for thermal comfort in a space and therefore they have the same influence in providing acceptable thermal conditions.

In particular, the mean radiant temperature, and consequently the operative temperature, are not evenly distributed and vary according to the location in the room. With radiant surface heating and cooling systems, the mean radiant temperature depends strongly on the surface temperatures of the heated/cooled surfaces, but also on the angle factors between the human body (position of occupant) and the room surfaces, as well as on the emissivity of the surfaces (ISO EN 7726).

Therefore, if the operative temperature is measured by a sensor, the result will be influenced not only by the position, but also by the shape, size and colour of the sensor.

The energy use or losses/gains in a space is due to transmission (including solar transmission) through exterior surfaces and ventilation. For ventilation, the room air temperature is the reference, whereas for the transmission the operative temperature is a better reference.

In HVAC (heating, ventilating and air-conditioning) systems, the most commonly used parameter to control indoor thermal environment is the air temperature $\left(t_{a}\right)$. This is accomplished either by a thermostat installed in each zone (room) or by a 'central' thermostat controlling the conditions of several zones based on the average air temperature set point of those zones.

\section{Simulation study of the influence of room sensor type on energy use and thermal comfort}

As the operative temperature is more closely related to the influence of room temperature on thermal comfort compared to air temperature, the use of operative temperature based thermostat control (TC-Top) have been 
studied and compared with air temperature based thermostat control (TC-Ta) in a few research papers.

Jain et al. compared the effects of the two controls on energy use in perimeter zones of highly glazed buildings in New Delhi (India) through simulation. Their results had shown that energy use in highly glazed buildings can be under-estimated by the use of TC-Ta. In another simulation study, Julien et al. found an increase of $18.7 \%$ on heating load when TC-Top was compared with TC-Ta. In a simulation study by Niu et. al., an increase of $7 \%$ in an office building in Hong Kong was found.

\section{The effect of HVAC system and geographical location}

Wang et.al. (2019) did a dynamic computer simulation study of energy use and indoor thermal environment of offices conditioned by means of three different HVAC systems: fan-coil system (FCS), floor heating/cooling system (FHCS), and radiant ceiling heating/cooling panel system (CHCPS). The study was based on whole year simulation for three cities, Copenhagen, Paris and Rome.

The building model used in all simulations included a central module of an office building with two offices separated by a corridor (Figure 1). Both the corridor and each of the offices were treated as separate zones. The selection of the building module was based on earlier work by Olesen and Dossi (2004) and Kolarik et.al. (2011). The total floor area used in modelling was 48.4 $\mathrm{m}^{2}$. The offices had only one outside façade. The other walls were assumed to be adiabatic. The building was a light construction with steel frame and thermal insulation. Figure 1 shows the studied room module.

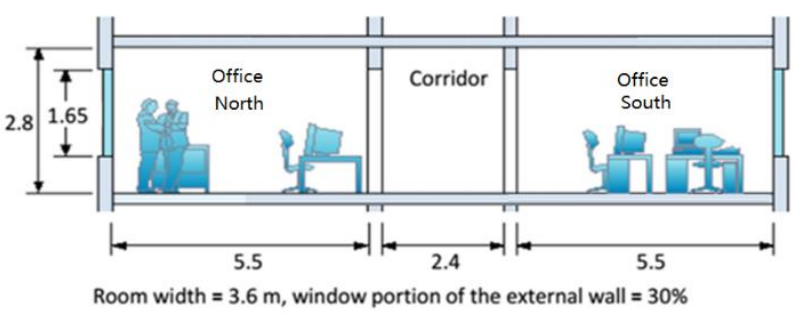

Figure 1: Section of the room module (reproduced from Olesen and Dossi, 2004). Dimensions in m.

The difference in monthly mean outdoor air temperature for the three cities are shown in Figure 2.

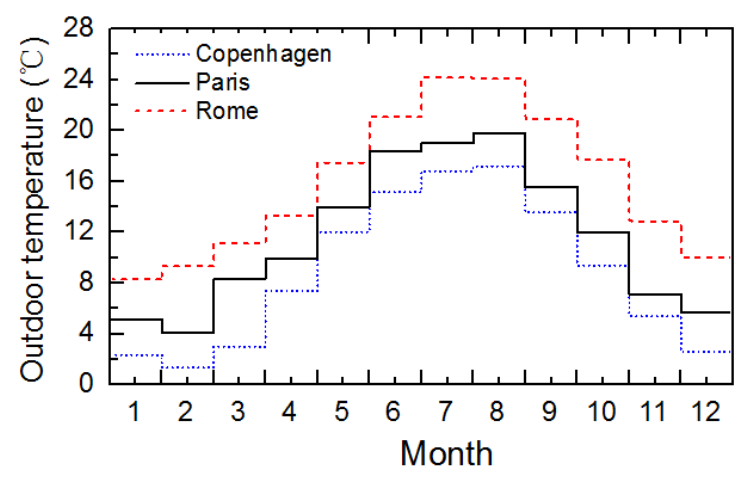

Figure 2: Average monthly outdoor temperature.
The internal heat load from people, light and equipment was set at $32 \mathrm{~W} / \mathrm{m}^{2}$. Windows in the office zones were equipped with only internal solar shading (light woven drape). When the solar radiation incident on an inside glass pane exceeded $200 \mathrm{~W} / \mathrm{m}^{2}$, internal drape would be activated. When the internal shading was drawn, the total shading coefficient of the window was multiplied by a factor of 0.71 and the short-wave shading coefficient of the window by a factor of 0.67 . The effect of the internal blinds on the U-value of the window was considered by a coefficient of 0.87 . The solar shading devices had simple two-position (on/off) control. For each type of simulated HVAC system, the indoor units cooperated with a ventilation system with heat recovery (effectiveness was 0.6 ). The ventilation system operated on weekdays from 8:00 to12:00 and 13:00 to 17:00 with lunch break. The supply airflow was $2 \mathrm{~L} /\left(\mathrm{s} . \mathrm{m}^{2}\right)$, which was about 2.6 air change per hour $(\mathrm{ACH})$, with constant supply temperature of $19{ }^{\circ} \mathrm{C}$. Natural infiltration would change according to the variation of climate file and would be much lower than $0.5 \mathrm{ACH}\left(0.39 \mathrm{~L} /\left(\mathrm{s} . \mathrm{m}^{2}\right)\right)$.

The temperature of offices and corridor was set to $25 \pm 1$ ${ }^{\circ} \mathrm{C}$ for cooling and $21 \pm 1{ }^{\circ} \mathrm{C}$ for heating. The cooling would be turned on when the temperature is higher than $26{ }^{\circ} \mathrm{C}$ and be turned off when the temperature is lower than $24{ }^{\circ} \mathrm{C}$. The heating would be turned on when the temperature is lower than $20{ }^{\circ} \mathrm{C}$ and be turned off when higher than $22{ }^{\circ} \mathrm{C}$. There were air- and operative temperature sensors in each room.

The fan-coils (FCS) operated during occupied hours with a supply water temperature of $15{ }^{\circ} \mathrm{C}$ for cooling and 40 ${ }^{\circ} \mathrm{C}$ for heating. The Floor Heating/Cooling System (FHCS) operated with a supply water temperature for cooling of $15^{\circ} \mathrm{C}$ and $40{ }^{\circ} \mathrm{C}$ for heating. In the simulation the lowest floor surface temperature was $21.8{ }^{\circ} \mathrm{C}$ and there was no condensation. The Radiant Ceiling Heating/Cooling Panel system (CHCPS) operated with a supply water temperature of $19{ }^{\circ} \mathrm{C}$ for cooling and $40{ }^{\circ} \mathrm{C}$ for heating. Considering the direct contact of cooling panel with air, to avoid condensation the supply water temperature of CHCPS was set higher than FCS and FHCS.

The amount of the energy used to condition the indoor space in the building module was determined and compared for all simulated HVAC systems. In the analysis, only two parts of energy ( $\mathrm{kWh}$ ) delivered to a particular HVAC system were considered: (1) zone heating/cooling - thermal energy supplied to indoor units; (2) ventilation system heating/cooling - thermal energy supplied to heating/cooling coils in air handling units to condition the air supplied to the zones. Since the main concern was to compare the effect of two thermostat controls, other energy cost by fans, pumps etc. was not included. 


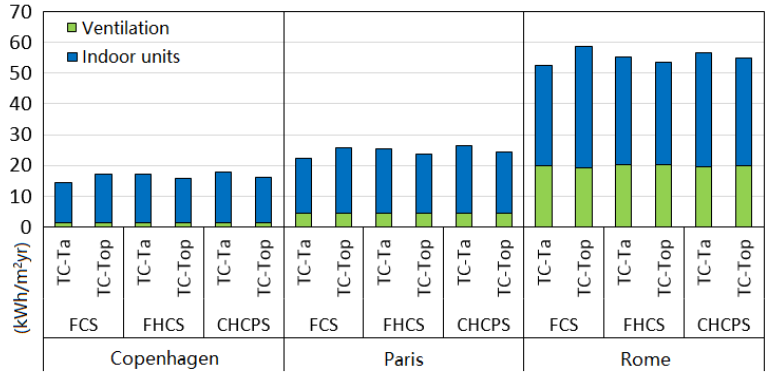

(a) Cooling energy use in simulated year

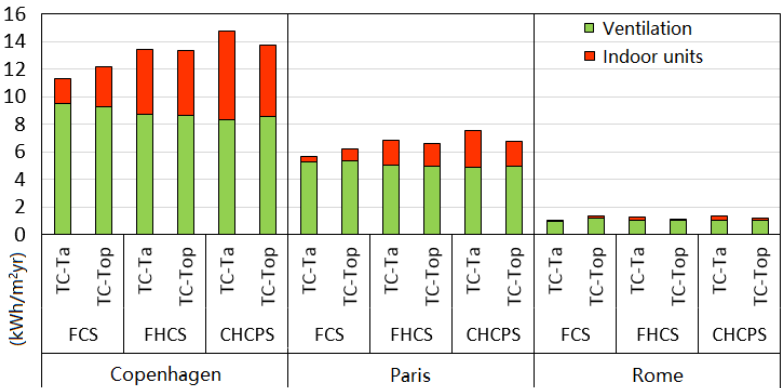

(b) Heating energy use in simulated year

Figure 3: Annual heating and cooling energy use.

The annual heating/cooling energy use per square meter of the space $\left(\mathrm{kWh} / \mathrm{m}^{2} . \mathrm{yr}\right)$ was calculated.

The results of the energy use calculations are shown in Figure 3. The values are the combined energy use for the three rooms, South, North and corridor.

Table 1. Total energy use for heating and cooling.

\begin{tabular}{|c|c|c|c|}
\hline Location & Type of system & $\begin{array}{l}\text { Type } \\
\text { of } \\
\text { control }\end{array}$ & $\begin{array}{c}\text { Total } \\
\text { cooling } \\
\text { and } \\
\text { heating } \\
\mathrm{kWh} / \mathrm{m}^{2} . \mathrm{yr}\end{array}$ \\
\hline \multirow{9}{*}{$\begin{array}{l}\text { Copenha } \\
\text { gen }\end{array}$} & \multirow{3}{*}{$\begin{array}{l}\text { Fan Coil } \\
\text { FCS }\end{array}$} & TC-Ta & 25.7 \\
\hline & & TC-Top & 29.3 \\
\hline & & $\Delta \mathrm{E}$ & $-14 \%$ \\
\hline & \multirow{3}{*}{$\begin{array}{l}\text { Floor } \\
\text { Heating/Cooling } \\
\text { FHCS }\end{array}$} & TC- $\mathrm{T}_{\mathrm{a}}$ & 30.6 \\
\hline & & TC-Top & 29.0 \\
\hline & & $\Delta E$ & $5 \%$ \\
\hline & \multirow{3}{*}{$\begin{array}{l}\text { Radiant Panel } \\
\text { Heating/Cooling }\end{array}$} & $\overline{T C-T_{a}}$ & 32.7 \\
\hline & & TC-Top & 30.0 \\
\hline & & $\Delta \mathrm{E}$ & $8 \%$ \\
\hline \multirow[t]{8}{*}{ Paris } & \multirow{3}{*}{$\begin{array}{l}\text { Fan Coil } \\
\text { FCS }\end{array}$} & TC-Ta & 28.0 \\
\hline & & TC-Top & 32.0 \\
\hline & & $\Delta E$ & $-14 \%$ \\
\hline & \multirow{3}{*}{$\begin{array}{l}\text { Floor } \\
\text { Heating/Cooling } \\
\text { FHCS }\end{array}$} & TC-Ta & 32.4 \\
\hline & & TC-Top & 30.4 \\
\hline & & $\Delta \mathrm{E}$ & $6 \%$ \\
\hline & \multirow{2}{*}{$\begin{array}{l}\text { Radiant Panel } \\
\text { Heating/Cooling }\end{array}$} & TC- $\mathrm{Ta}_{\mathrm{a}}$ & 33.8 \\
\hline & & TC-Top & 31.2 \\
\hline
\end{tabular}

\begin{tabular}{|c|c|c|c|}
\hline & CHCPS & $\Delta \mathrm{E}$ & $8 \%$ \\
\hline \multirow[t]{9}{*}{ Rome } & \multirow{3}{*}{$\begin{array}{l}\text { Fan Coil } \\
\text { FCS }\end{array}$} & TC- $\mathrm{T}_{\mathrm{a}}$ & 53.4 \\
\hline & & TC-Top & 60.2 \\
\hline & & $\Delta E$ & $-13 \%$ \\
\hline & \multirow{3}{*}{$\begin{array}{l}\text { Floor } \\
\text { Heating/Cooling } \\
\text { FHCS }\end{array}$} & TC-Ta & 56.6 \\
\hline & & TC-Top & 54.8 \\
\hline & & $\Delta \mathrm{E}$ & $3 \%$ \\
\hline & \multirow{3}{*}{$\begin{array}{l}\text { Radiant Panel } \\
\text { Heating/Cooling }\end{array}$} & TC- $\mathrm{T}_{\mathrm{a}}$ & 58.0 \\
\hline & & TC-Top & 56.0 \\
\hline & & $\Delta \mathrm{E}$ & $3 \%$ \\
\hline
\end{tabular}

Table 1 shows the estimated total energy for heating and cooling for air (TC-Ta) and operative (TC-Top) temperature control together with the calculated \% difference $(\Delta E)$.

To evaluate the performance of type of control, the resulting comfort in the rooms must also be considered. In this study, the South office will be used as most effect is expected here because of the sun radiation. The thermal comfort was analysed according to EN 16798-1 (or ISO 17772-1). Table 2 shows the different thermal comfort categories according to EN 16798-1 and ISO 17772-1.

Table 2. Thermal comfort categories according to EN 16798-1 (or ISO 17772-1).

\begin{tabular}{|l|l|l|}
\hline \multirow{2}{*}{ Category } & \multicolumn{2}{|l|}{ Operative temperature $\left({ }^{\circ} \mathrm{C}\right)$} \\
\cline { 2 - 3 } & During cooling & During heating \\
\hline I & $23.5-25.5$ & $21.0-23.0$ \\
\hline II & $23.0-26.0$ & $20.0-24.0$ \\
\hline III & $22.0-27.0$ & $19.0-25.0$ \\
\hline IV & $<22.0$ or $>27.0$ & $<19.0$ or $>25.0$ \\
\hline
\end{tabular}

The \%-distribution of the operative temperature in the 4 categories in Table 2 was calculated from the results of the simulations. Only the hours of occupancy from 08:00 to17:00 is analysed. The results for the south office is shown in Figure 4. 




Figure 4: Statistics of thermal comfort levels in South office.

The control mode has a significant influence on the resulting thermal comfort in the room.

For a convective system (FCS), the comfort improvements by using an operative temperature control is very significant. Especially for the warmer environment like Paris and Rome, where more cooling is needed. By using the operative temperature as thermostat, the number of hours in Cat IV was reduced to less than 5\% even in the warmest climate. However, this behaviour results in an energy penalty of $13-14 \%$ (Table 1).

For a radiant system, the difference between the two control modes are less significant. In both control modes the number of hours in Cat IV is 5\% or less. Using an air temperature control will improve comfort in a room heated/cooled by a radiant system. The number of hours in Cat IV will be reduced to $2 \%$ or less. This also come with an energy penalty of $3-8 \%$.

During cooling, the supply water temperature of FHCS was set as $15{ }^{\circ} \mathrm{C}$ and at $19{ }^{\circ} \mathrm{C}$ for CHCPS. In the simulation, the lowest temperature of the cooling surface was $21.8^{\circ} \mathrm{C}$ for FHCS and $21.3^{\circ} \mathrm{C}$ for CHCPS, without any risk of condensation. As the heat exchange coefficient for a cooled ceiling is higher than for a cooled floor, the ceiling panels can provide better cooling than the floor. This explained the result that CHCPS had better thermal comfort conditions than FHCS under the same control conditions during cooling, especially when located in Rome.

As the window size has a very significant influence on the load and the mean radiant temperature in a room, a further simulation was made with a $100 \%$ window façade instead of $30 \%$. The simulation was only made for Paris. As the larger window required more energy for cooling, the radiant ceiling panels were simulated with a supply temperature for cooling of $19 \mathrm{C}^{\circ}$ and $16 \mathrm{C}^{\circ}$. The results of the energy calculations are shown in Table 3 and Figure 5.
Table 3. Total energy use for heating and cooling for two window sizes.

\begin{tabular}{|c|c|c|c|}
\hline \multirow{3}{*}{\multicolumn{2}{|c|}{$\begin{array}{l}\text { Fan Coil FCS } \\
30 \% \text { window }\end{array}$}} & TC-Ta & 28.0 \\
\hline & & TC-Top & 32.0 \\
\hline & & $\Delta E$ & $-14 \%$ \\
\hline \multirow{12}{*}{ Paris } & \multirow{3}{*}{$\begin{array}{l}\text { Fan Coil FCS } \\
100 \% \text { window }\end{array}$} & TC- $\mathrm{T}_{\mathrm{a}}$ & 44.1 \\
\hline & & TC-Top & 59.5 \\
\hline & & $\Delta E$ & $-35 \%$ \\
\hline & \multirow{3}{*}{$\begin{array}{l}\text { Radiant } \\
\text { Heating/Cooling } \\
\text { CHCPS } \\
30 \% \text { window } \\
19^{\circ} \mathrm{C} \text {, supply }\end{array}$} & $\mathrm{TC}-\mathrm{T}_{\mathrm{a}}$ & 33.8 \\
\hline & & TC-Top & 31.2 \\
\hline & & $\Delta \mathrm{E}$ & $8 \%$ \\
\hline & \multirow{3}{*}{$\begin{array}{l}\text { Radiant } \\
\text { Heating/Cooling } \\
\text { CHCPS } \\
100 \% \text { window } \\
19^{\circ} \mathrm{C} \text {, supply } \\
\end{array}$} & TC-Ta & 61.6 \\
\hline & & $\begin{array}{l}\text { TC- } \\
\text { Top }_{\text {op }}\end{array}$ & 55.2 \\
\hline & & $\Delta \mathrm{E}$ & $10 \%$ \\
\hline & \multirow{3}{*}{$\begin{array}{l}\text { Radiant } \\
\text { Heating/Cooling } \\
\text { CHCPS } \\
100 \% \text { window } \\
16^{\circ} \mathrm{C} \text {, supply }\end{array}$} & TC- $\mathrm{T}_{\mathrm{a}}$ & 65.4 \\
\hline & & TC-Top & 57.3 \\
\hline & & $\Delta E$ & $12 \%$ \\
\hline
\end{tabular}
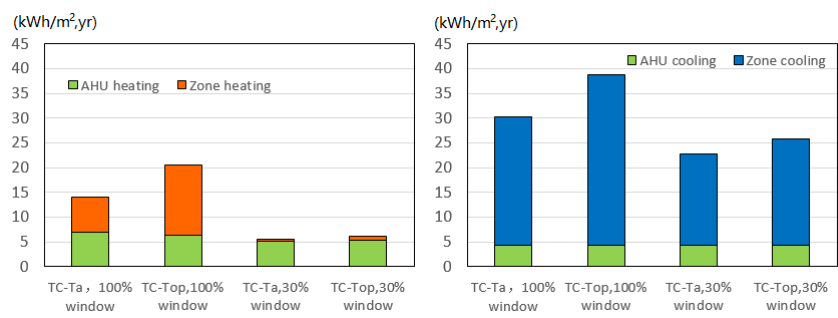

Figure 5: Annual heating and cooling energy use for fan coil and two window sizes. 


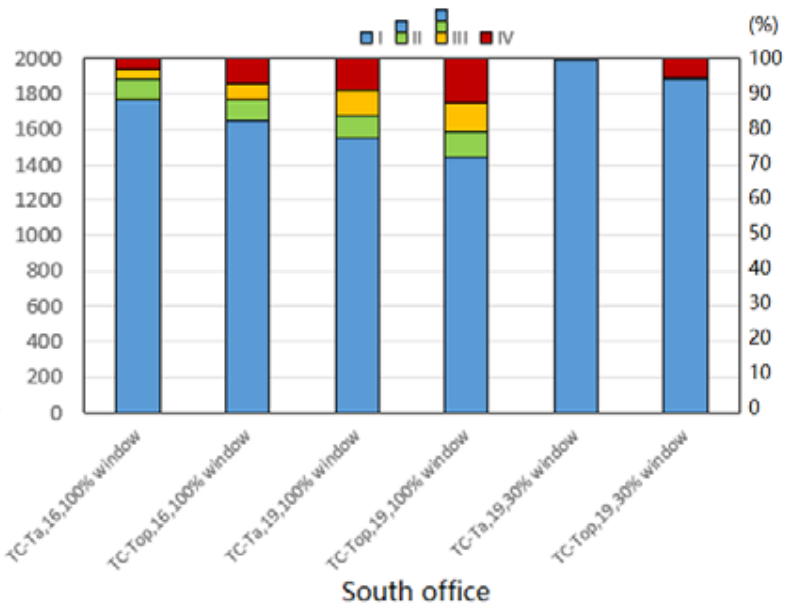

Figure 6: Statistics of thermal comfort levels in South office for radiant ceiling panels.

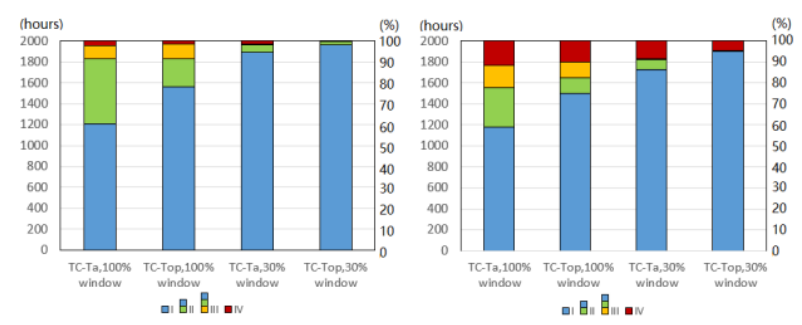

Figure 7: Statistics of thermal comfort levels in North office (left) and South office (right) for fan coil system.

\section{Experimental testing of the influence of sensor colour, shape and position}

In an experimental study by Simone et. al. (2007) several types of sensors (ellipsoid Figure. 8, sphere Figure 9 , half-sphere Figure 10, flat, grey, black, white, polished), were used to measure the operative temperature in a chamber with different combinations of air temperature and radiant heated or cooled surfaces. Besides comparing the type of sensor, the influence of the sensor position in the room was experimentally investigated. All sensors were calibrated and the accuracy was $\pm 0.2 \mathrm{~K}$.

\section{Sensor size}

The optimal size of an operative temperature sensor was investigated by looking at the theory for convective and radiant heat exchange for an object. In moderate indoor thermal environments the air velocity is normally lower than $0.15 \mathrm{~m} / \mathrm{s}$ and the temperature difference between airand mean radiant temperature is lower than $5 \mathrm{~K}$. For such boundary conditions a diameter between 0.03 and $0.05 \mathrm{~m}$ for the sphere, and a length between 0.04 and $0.07 \mathrm{~m}$ for the flat shape may suffice (the one used in the present experiment had $3 \mathrm{~cm}$ diameter). The lower the air velocity the smaller the required sensor.

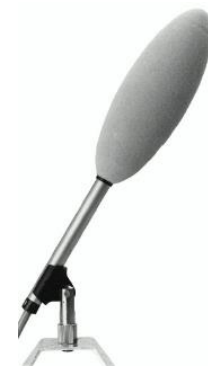

Figure 8: Ellipsoidshaped sensor.

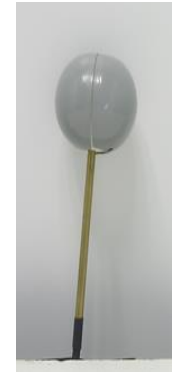

\section{Figure 9:} Spherical sensor.

Diameter

$4 \mathrm{~cm}$.



Figure 10: Half-sphere sensor.

Diameter 4

$\mathrm{cm}$.



Figure

11: Air

temperatu

re sensor.

\section{Sensor colour}

Three coloured sensors (black, grey, white) and one polished aluminium flat sensor were used in the experiment. The sensors were first exposed to a radiant ceiling (about $42{ }^{\circ} \mathrm{C}$ ). The results in Figure 12 show that

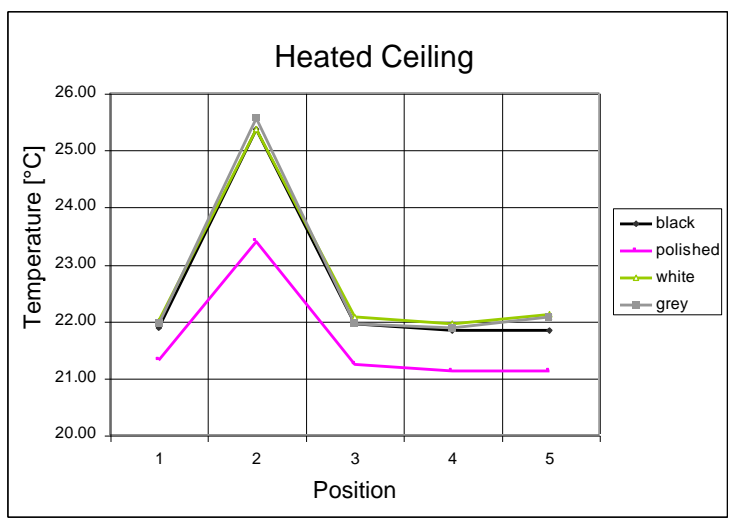

Figure 12: Sample of measured temperatures for flat sensors exposed to heated ceiling.

the colour of a sensor is not important when exposed to long-wave infrared radiation. A polished sensor, however, will reflect more of the radiation and show less influence. In the present test the polished sensor showed 1 to $2 \mathrm{~K}$ lower temperature, depending on the position to the heated ceiling. Room sensors or thermostats may often be exposed to short-wave radiation from direct or diffuse sunlight. This was tested in another experiment. The sensors were exposed to short-wave radiation produced by a high temperature sun-spot lamp. The sensors' direction to the lamp was changed from a perpendicular (position 1a), $45^{\circ}$ angle (position 1b) and a $90^{\circ}$ angle (position 1c). 


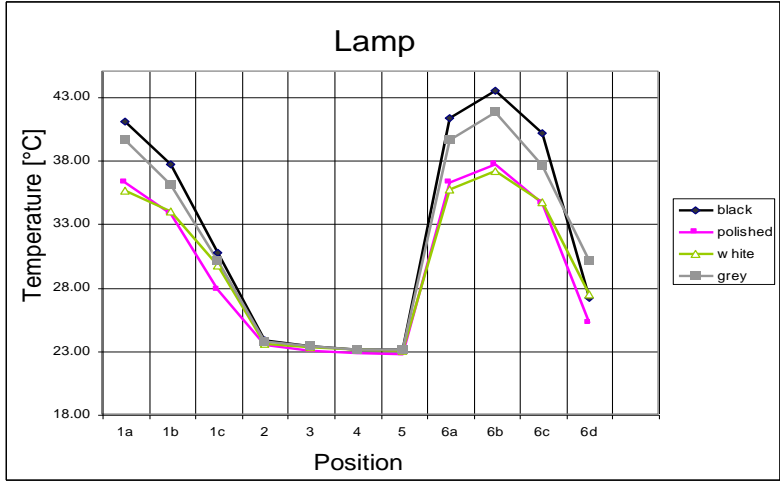

Figure 13: Influence of sensor colour when exposed to sun-lamp at different angles.

The results in Figure 13 shows that the colour and finishing of the sensors had a significant influence on the temperature reading when exposed to short-wave radiation. The lowest effect was on a white and a polished sensor; the highest was on the black sensor. The highest differences (approximately $6 \mathrm{~K}$ between black and white) appeared when all sensors were placed $3.5 \mathrm{~m}$ from the lamp and faced front perpendicularly to the lamp. By turning around the horizontal axis from the perpendicularly facing position $\left(0^{\circ}\right)$ to parallel with the radiation from the lamp $\left(90^{\circ}\right)$, sensors receive less shortwave radiation and the influence decreases. In a real room, the angle of the short-wave sun radiation varies during the day. Generally, a grey sensor gives intermediate results between black and white (see Figures 12 and 13), but closer to the black, and the polished sensor gives results very close to the white, especially when the sensors face the light source directly.

\section{Influence of sensor shape and position}

Different sensor types (Figures 8-11) were positioned in a test room with a heated/cooled window, heated/cooled ceiling, heated/cooled wall, heated floor, and combinations. All sensors were positioned at $1.1 \mathrm{~m}$ height. The reference was an ellipsoid shaped sensor in the centre of the test room. The flat sensor was circular 3 $\mathrm{cm}$ diameter and painted grey.

In all cases the air temperature in the test room was controlled by piston flow (uniform air temperature distribution) through a perforated floor in the range (19$\left.21{ }^{\circ} \mathrm{C}\right)$.

Table 4 shows the difference between the reference operative temperatures in the centre (ellipsoid sensor) compared to air and the measured sensor temperatures in different locations. This is influenced by both the difference in sensor type and position. The radiant temperature asymmetry is used to describe the nonuniformity of the radiant environment.
Table 4. Comparison of measured sensor temperature in different locations with the reference operative temperature in the centre (ellipsoid).

$B$ : sensors at side wall; A: sensors at centre facing window; E: sensors at backwall facing window.

\begin{tabular}{|c|c|c|c|c|c|c|}
\hline \multirow[t]{2}{*}{ Set-up } & \multicolumn{2}{|c|}{$\begin{array}{c}\text { Radiant } \\
\text { asymmetry, } \\
\Delta \mathrm{t}_{\mathrm{p}, \max } \mathrm{K}\end{array}$} & \multicolumn{4}{|c|}{$\begin{array}{c}\Delta \mathrm{T}_{\text {op }} \text { (ellipsoid-sensors) } \\
\mathrm{K}\end{array}$} \\
\hline & Hor. & Ver. & sensors & B & $A$ & $E$ \\
\hline \multirow{4}{*}{$\begin{array}{l}\text { Cooled } \\
\text { window }\end{array}$} & \multirow{4}{*}{0.7} & \multirow{4}{*}{1.3} & air & -1.0 & -1.0 & -1.0 \\
\hline & & & sphere & -0.6 & -0.9 & -1.2 \\
\hline & & & flat & -0.8 & -0.1 & -0.9 \\
\hline & & & $\begin{array}{l}\text { half } \\
\text { sphere }\end{array}$ & -0.1 & -0.4 & -0.8 \\
\hline \multirow{4}{*}{$\begin{array}{l}\text { Cooled } \\
\text { Window } \\
\text { Heated } \\
\text { Ceiling }\end{array}$} & \multirow{4}{*}{15.6} & \multirow{4}{*}{1.6} & air & 0.9 & 0.8 & 1.0 \\
\hline & & & sphere & 0.1 & 0.1 & 0.1 \\
\hline & & & flat & -0.8 & 0.9 & -0.2 \\
\hline & & & $\begin{array}{l}\text { half } \\
\text { sphere }\end{array}$ & -0.4 & 0.6 & -0.1 \\
\hline \multirow{4}{*}{$\begin{array}{l}\text { Heated } \\
\text { Ceiling }\end{array}$} & \multirow{4}{*}{18.8} & \multirow{4}{*}{0.2} & air & 1.9 & 1.6 & 1.4 \\
\hline & & & sphere & 0.4 & 0.2 & 0.1 \\
\hline & & & flat & -0.4 & -0.2 & -0.2 \\
\hline & & & $\begin{array}{l}\text { half } \\
\text { sphere }\end{array}$ & -0.2 & -0.2 & -0.2 \\
\hline \multirow{4}{*}{$\begin{array}{l}\text { Heated } \\
\text { floor }\end{array}$} & \multirow{4}{*}{6.1} & \multirow{4}{*}{0.2} & air & 0.1 & 0.1 & 0.4 \\
\hline & & & sphere & 0.0 & -0.1 & 0.1 \\
\hline & & & flat & -0.2 & -0.2 & 0.1 \\
\hline & & & $\begin{array}{l}\text { half } \\
\text { sphere }\end{array}$ & -0.2 & -0.2 & -0.1 \\
\hline
\end{tabular}

Column A shows the results for all sensors in the centre. This comparison is thus influenced only by the type of sensor and not the position. Even if in some cases the radiant temperature asymmetry was quite big, the difference between operative and air temperature were in only one case higher than $1 \mathrm{~K}$ (heated ceiling). Column B and $\mathrm{C}$ show the difference between the reference operative temperatures in the centre compared to the measured sensor temperatures in different locations. This is influenced by both the difference in sensor type and position. In most cases the results show relatively small differences between the sensors and the reference operative temperature in the centre. However, the sphere in general is not better than the flat and the half-sphere. In most cases the difference between local air temperature and operative temperature in the centre is bigger than the difference between the other sensors and the operative temperature. 


\section{Discussion}

Building simulation studies show that the impact of using a thermostat control based on air temperature or on operative temperature can be very significant both regarding energy use and thermal comfort. The largest differences are found if an air system like fan coil is used. If controlled by air temperature the thermal comfort is not acceptable. Therefore it is recommended to use an operative temperature control for air systems. The improved comfort with an operative temperature control will result in a significantly higher (> 14\%) energy use. For a radiant system like floor heating/cooling or radiant ceiling panels, the difference between using air temperature control compared to operative temperature control is smaller both regarding thermal comfort and energy use. For comfort, air temperature control is the best for radiant systems. The reasons are the larger difference between air- and operative temperature in spaces with air systems. With radiant systems the radiant surface do compensate for a cold (or warm) window, so the difference become smaller (Kazanci et al. 2018).

The occupant behaviour is an important factor and may counteract for differences in control systems. If the occupant is feeling too warm or cold he/she will adjust the thermostat setting to provide better comfort and in this way compensate for any differences between thermostat set-point and operative temperature in the occupied space. This is possible in single office conditions; but may be more difficult in landscape offices.

Another development in the field of temperature measurements in buildings is the use of wireless indoor environmental quality (IEQ) sensors. Their increasing use in buildings might provide the possibility of using them instead of the typical wired sensors in Building Management Systems (BMS). However, their use in BMS will have different effects on indoor environment, energy performance and system operation. Recent studies identified the measurement capabilities of state-of-the-art wireless IEQ sensors (Mylonas et al. 2019).

\section{Conclusion}

The results showed that air temperature based thermostat control and operative temperature based thermostat control had different impacts on fan-coil system and radiant systems. For fan-coil system, the use of operative temperature based thermostat control had better thermal comfort conditions and higher energy use than that of air temperature based thermostat control. For the two radiant systems, the results were the opposite. The results were almost the same in the different geographical locations simulated. Besides, the thermal comfort difference between the two controls of north office was smaller than that of south office.

For fan-coil system, in south office, compared with air temperature based thermostat control, the hours of Cat. I $(-0.2 \leq \mathrm{PMV} \leq 0.2)$ increased $8 \%$ for building in Copenhagen, $9 \%$ for Paris and $14 \%$ for Rome. Meanwhile, total energy supply increased $14 \%$ in Copenhagen and Paris and $13 \%$ in Rome. For radiant systems, the total energy use reduced $3 \%$ to $8 \%$ depending on location and type of system when operative temperature based control was used.

The experimental study showed an influence of the thermostat position in a room on the thermal comfort in the occupied space.

\section{Acknowledgement}

This study has been financially supported by the National Natural Science Foundation of China (No.51678314 and No.51778305) and by the International Centre for Indoor Environment and Energy, DTU. This study was also financially supported by Mitsubishi Electric R\&D Centre Europe BV as a part of the project "Intelligent Comfort Control Development".

\section{References}

International Organisation for Standardisation (2017). Energy performance of buildings -- Sensible and latent heat loads and internal temperatures -- Part 1: Generic calculation procedures (ISO 52017-1).

ASHRAE Standard 55 (2016), Thermal Environmental Conditions for Human Occupancy, Atlanta: American Society of Heating, Refrigerating, and Air conditioning Engineers, Inc.

EN ISO 7730. (2005). Ergonomics of the thermal environment - Analytical determination and interpretation of thermal comfort using calculation of the PMV and PPD indices and local thermal comfort criteria, International Organization for Standardization, Genève, Switzerland

EN 16798-1 (2019). Energy performance of buildings Part 1: Indoor environmental input parameters for design and assessment of energy performance of buildings addressing indoor air quality, thermal environment, lighting and acoustics. European Committee for Standardization, Brussels, Belgium.

ISO 17772-1 (2017): Energy performance of buildings Indoor environmental quality. Part 1: Indoor environmental input parameters for the design and assessment of energy performance in buildings," International Organization for Standardization, Genève, Switzerland.

ISO EN 7726, (1998). Ergonomics of the thermal environment - Instruments for measuring physical quantities, International Organization for Standardization, Genève, Switzerland

Jain,V., V. Garg, J. Mathur, S. Dhaka (2011). Effect of operative temperature based thermostat control as compared to air temperature based control on energy consumption in highly glazed buildings. Proceedings of Building Simulation 2011 November, Sydney: 2688-2695.

Julien,C., A. Jerome and R. Philipe(2009). Simulation of control options for HVAC management of a typical office building. Climate 2009, Lisbon, Portugal. 
Mylonas, A., Kazanci, O. B., Andersen, R. K., \& Olesen, B. W. (2019). Capabilities and limitations of commercially available wireless indoor environment sensors. Atlanta, GA: American Society of Heating, Refrigerating and Air-Conditioning Engineers. Proceedings of 2019 ASHRAE Winter Conference.

Mylonas, A., Kazanci, O. B., Andersen, R. K., \& Olesen, B. W. (2019). Capabilities and limitations of wireless $\mathrm{CO} 2$, temperature and relative humidity sensors. Building and Environment, 362-374. doi:10.1016/j.buildenv.2019.03.012

Niu, J.I:, and J. Burnett (1998). Integrating radiant/ operative temperature controls into building energy simulations. ASHRAE Transactions 1998; 104(2): 210-217.

Kazanci, O. B., Khovalyg, D., Takayoshi, I., Uno, Y., Ukiana, T., \& Olesen, B. W. (2018). Experimental comparison of the thermal indoor environment created by a radiant, and a combined radiant and convective cooling system. Proceedings of Roomvent \& Ventilation 2018, (pp. 223-228). Espoo.

Kolarik, Jakub, Jørn Toftum and Bjarne W. Olesen (2011). Simulation of energy use, human thermal comfort and office work performance in buildings with moderately drifting operative temperatures. Energy \& Buildings 2011; 43: 2988-2997

Kontes,G.D., Georgios I. Giannakis, Philip Horn et al. (2017). Using Thermostats for Indoor Climate Control in Office Buildings: The Effect on Thermal Comfort. Energies,2017;(10):1368-22,DOI: 10.3390/en 10091368

Olesen,B.W. and Francesco CurrÒ Dossi.(2004) Operation and Control of Activated Slab Heating and Cooling Systems. CIB World Building Congress, 2004

Simone, A., J. Babiak, M. Bullo, G. Langkilde, B.W. Olesen (2007). Operative temperature control of radiant surface heating and cooling systems. Proceedings of Clima 2007 Wellbeing Indoors

Wang, H., Olesen, B. W., \& Kazanci, O. B. (2019). Using thermostats for indoor climate control in offices: The effect on thermal comfort and heating/cooling energy use. Energy and Buildings, 188-189, 71-83. doi:10.1016/j.enbuild.2018.12.030 